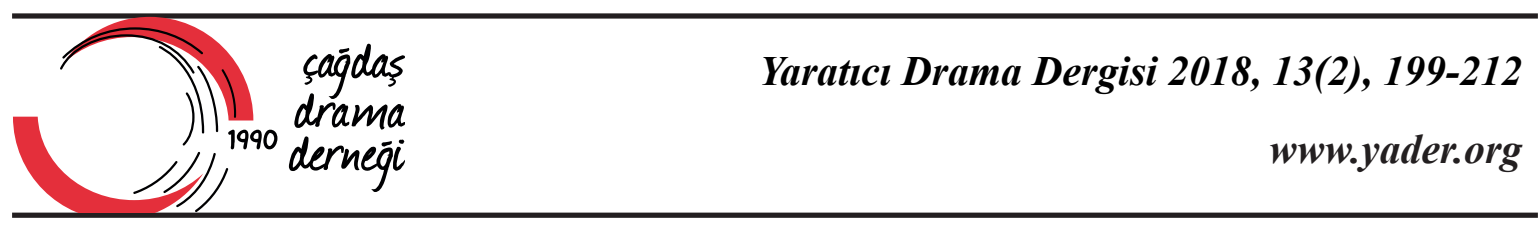

\title{
İlkokula Devam Eden Kaynaştırma Öğrencilerinin Sınıf İçi Etkinliklere Katılım Düzeyine Yaratıcı Drama Yönteminin Etkisinin İncelenmesi
}

Fatih Kıvanç Erdoğan'

Süleyman Arslantaş ${ }^{2}$

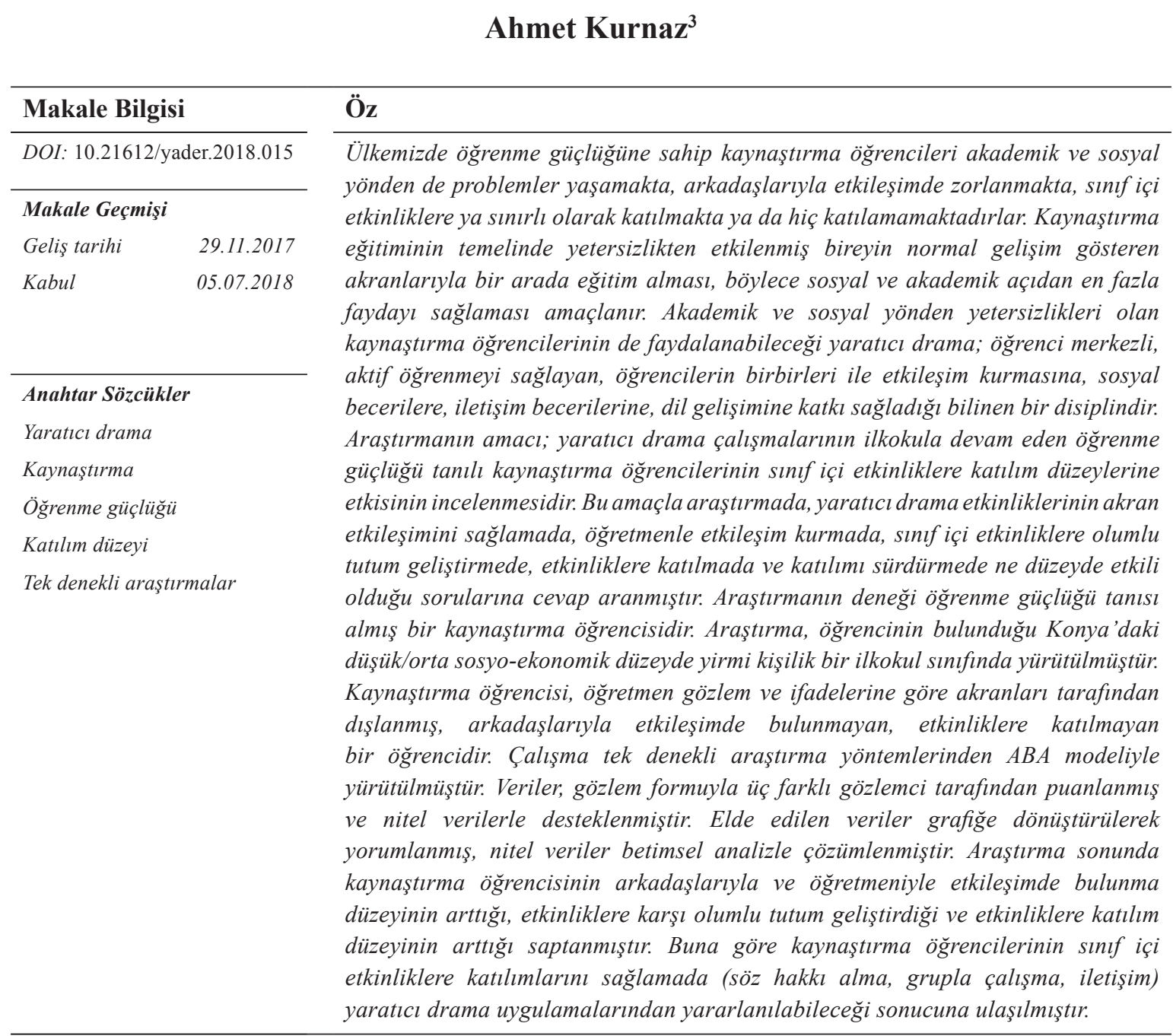

Öğretmen, AKD Kids anaokulu, E-posta: 94kivanc@gmail.com

2 Dr. Öğr. Üy., Necmettin Erbakan Üniversitesi, E-posta: gsarslantas@hotmail.com

3 Dr. Öğr. Üy., Necmettin Erbakan Üniversites, E-posta: ahkurnaz@hotmail.com 


\begin{tabular}{lr}
\hline Article Info \\
\hline DOI: $10.21612 /$ yader.2018.015 \\
\hline Article History & \\
Received & 29.11 .2017 \\
Accepted & 05.07 .2018
\end{tabular}

The Analysis of the Effect of Creative Drama Activities on Participation Levels of Elementary School Inclusive Students Diagnosed with a Learning Disability in Classroom Activities

Keywords

Creative drama

Inclusion

Learning disabilities

Level of participation

Single subject research

\section{Abstract}

In our country, inclusive students with intellectual disabilities and learning disabilities typically experience difficulties both socially and academically and have difficulty in interacting with their peers. They infrequently or never participate in classroom activities. Inclusive education is based on the principle that aims to educate individuals affected by disability along with their non-disabled peers on the same basis and to be helpful to them both socially and academically. Creative drama, from which inclusive students could benefit socially and academically, is a discipline based on a student-centered approach enabling active learning, helping students interact with each other, developing their social and communication skills and improving language developments as well. The purpose of this study is to investigate the effect of creative drama activities on participation levels of elementary school inclusive students diagnosed with a learning disability to classroom activities. Hence, answers to the following questions were sought: "To what extent are creative drama activities effective in maintaining peer relationships, interacting with the teacher, developing positive attitudes towards in-class activities, participating in the activities and maintaining involvement? The subject of this study is an inclusive student who has been diagnosed with a learning disability. The research has been conducted in an elementary school class of 20 pupils in a low/middle socio-economic setting in Konya, where the student lives. According to teacher observations and expressions, the inclusive student is a pupil excluded by his peers, not interacting with his friends and not participating in activities. One of the single-subject research designs, 'ABA pattern'was used in this study. The data were obtained by 3 different observers through observation forms and supported by the qualitative data. The data obtained were transformed into graphics and findings were interpreted. Qualitative data were analyzed through descriptive analysis. At the end of the research, it was determined that the level of interaction between the inclusive student and his peers and teacher increased, he developed a positive attitude towards activities and his levels of participation in activities increased. Accordingly, creative drama practices can be used to ensure that inclusive students participate in classroom activities (asking for permission to speak, working in groups, communication). 


\section{Giriş}

Türk Milli Eğitimin genel amaçlarının ikinci maddesinde ruh ve duygu bakımından dengeli ve sağlıklı, ilgi kabiliyetlerini geliştiren, birlikte iş görebilen, kendisi mutlu ve toplumu da mutlu kılacak bireyler yetiştirilmesinden söz edilmektedir (MEB 1973). Genel amaçlar doğrultusunda tüm çocukların birbiriyle uyumlu, saygı ve hoşgörü çerçevesinde ilişkiler kurması beklenilmektedir. $\mathrm{Bu}$ amaçlar özel gereksinimli bireyler için de ulaşılması gereken hayati amaçlardır. Özel gereksinimli birey, MEB Özel Eğitim Hizmetleri 31.05.2006 tarih ve 26184 sayılı Resmî Gazete yönetmeliğinde "çeşitli nedenlerle bireysel özellikleri ve eğitim yeterlikleri açısından akranlarından beklenilen düzeyde anlamlı farklılık gösteren birey” olarak tanımlanmıştır.

Ülkemizde tarama ve tanılamanın gelişmesi sonucunda özel eğitime gereksinimli bireylerin eğitim ortamlarındaki sayıları artmış, bu da beraberinde en az kısıtlayıcı ortamda sürdürülen kaynaştırma eğitiminde farklı ihtiyaçlar doğurmuştur. Kaynaştırma, özel gereksinimli öğrencinin genel eğitim okullarında normal gelişim gösteren akranlarıyla birlikte, gerektiğinde kendisine ve sınıf öğretmenine destek hizmetler sağlamak suretiyle öğretim görmesidir (Sucuoğlu ve Kargın 2006). Başka bir tanıma göre kaynaştırma; özel eğitim gerektiren bireylerin, yetersizliği olmayan akranları ile birlikte eğitim ve öğretimlerini resmi ve özel okul öncesi, ilköğretim, ortaöğretim ve yaygın eğitim kurumlarında sürdürmeleri esasına dayanan destek eğitim hizmetlerinin sağlandığ özel eğitim uygulamalarıdır (Batu ve Kırcaali-İftar, 2006). Kaynaştırma eğitiminde sınıf öğretmeni, sınıfta öğrenim gören öğrenciler, veliler ile destek eğitim öğretmeni bu sürecin dinamiklerindendir. Sınıf öğretmeninin kaynaştırmaya ilişkin olumlu tutumu ve yeterliliği eğitimin kalitesini büyük ölçüde etkiler. Kaynaştırmaya yönelik tutumlar, öğretmen yeterlilikleri, sınıfların fiziksel koşulları ve akran tutumları kaynaştırma öğrencilerinin var olan potansiyellerini ortaya koymada, ihtiyaçları olan eğitimin tamamını karşılamada olumsuzluklar yaratabilir.

Kaynaştırma öğrencisinin mevcut potansiyelini ortaya koyamaması, arkadaşları tarafından kabullenilmemesi, sınıfa sosyal uyum sağlayamaması, yalnız kalması, kendini ifade edecek ortam ve firsat bulamaması öğrencinin hem akademik hem de sosyal becerilerini sınırlandırmamakta ve normal gelişim gösteren akranlarıyla arasındaki farkın açılmasına neden olmaktadır (Sucuoğlu ve Kargın, 2006). Kaynaştırma öğrencisinin sınıf içinde kabulünü sağlama, bu konuda öğretmen yeterlilikleri, tutum değiştirme, öğretimsel düzenlemeler gibi alan yazın çalışmaları yapılsa da kaynaştırma öğrencileri sosyal ve akademik yönden hâlâ dezavantajlı, etiketlenmiş ve yalnız öğrencilerdir.

Kaynaştırma yoluyla eğitim 2006 tarihli ve 26184 sayılı Resmi Gazete'de; özel eğitime ihtiyacı olan bireylerin eğitimlerini, destek eğitim hizmetleri de sağlanarak yetersizliği olmayan akranları ile birlikte resmî ve özel okul öncesi, ilköğretim, ortaöğretim ve yaygın eğitim kurumlarında sürdürmeleri esasına dayanan özel eğitim uygulamaları olarak tanımlanmıştır. Kaynaştırma yoluyla eğitimin özel gereksinimli birey için birçok faydası vardır ve en az kısıtlanmış ortamda yapılan öğretimsel düzenlemelerde başarılı oldukları yapılan araştırmalarda görülmektedir (Güzel-Özmen, 2009). Kaynaştırma yoluyla eğitimin özel gereksinimli birey dışında ailelere, normal gelişim gösteren bireylere ve öğretmenlere de birçok katkısı vardır. En az kısıtlayıcı ortam özel gereksinimli bireyin toplumla bütünleşmesini kolaylaştıracak, akran öğretimi, gözleyerek öğrenme gibi durumlardan da faydalanmasını sağlayacaktır. Özel gereksinimli bireylerin toplumla bütünleşmesinin önündeki engellerden biri olan olumsuz tutumlarla başa çıkılmasında da kaynaştırma yoluyla eğitim iyi bir yoldur. Özel gereksinimli bireyin ötekileştirilmesi onun anlaşılamamasına, yalnız kalmasına neden 
olmaktadır. En az kısıtlayıcı ortamdaki özel gereksinimli bireyin akranlarıyla kuracağı etkileşim, bireylerin birbirini anlamasını sağlayacak, bu da bütünleşmeye katkıda bulunacaktır. Bu nedenle özel gereksinimli bireylerin eşitlikçi bir yaklaşım içerisinde akranlarıyla etkileşimde bulunması için alanlar artırılmalı ya da var olan alanlara ulaşmaları sağlanmalıdır. Tüm bireyler arasında etkileşim sağlayan disiplinlerden biri de yaratıcı dramadır (Genç, 2003; Adıgüzel, 2013). Yaratıcı drama ile ilgili birçok tanım yer almaktadır Adıgüzel (2013)'e göre; "Bir grubu oluşturan üyelerin yaşam deneyimlerinden yola çıkarak, bir amacın, düşüncenin, doğaçlama, rol oynama ve diğer tekniklerden yararlanılarak canlandırılmasıdır. Bu canlandırma süreçleri deneyimli lider/eğitmen tarafından yürütülürken şimdi ve burada ilkesine, kendiliğindenliğe, mış gibi yapmaya dayalıdır ve oyunun genel özelliklerinden yararlanır." San (2002) ise yaratıcı dramayı; "Doğaçlama, rol oynama gibi tiyatro ya da drama tekniklerinden yararlanılarak, bir grup çalışması içinde, bireylerin bir yaşantıyı, bir olayı, bir fikri, kimi zaman bir soyut kavramı ya da bir davranışı eski yaşamların tekrar gözden geçirilmesi yoluyla canlandırılması" şeklinde tanımlamıştır. Ayrıca Isenberg ve Jalongo (1993) yaratıcı dramayı, çocukların bedensel ve kinestetik kapasitelerini artırarak, grupla çalışma becerilerini ve birlikte öğrenme becerilerini geliştirdikleri bir süreç olarak tanımlamışlardır.

Yaratıcı drama, diğer alanlardaki öğrenmeleri geliştirmek ve motivasyonu artırmak için kullanılabilir. Yaratıcı dramaya katılım, dil ve iletişim yeteneklerini, problem çözme becerilerini ve yaratıcılığı geliştirebilmekle birlikte, olumlu benlik kavramını, sosyal farkındalığı, empatiyi artırabilmeye, değer ve tutumları aydınlatabilmeye ve tiyatro sanatını anlamaya potansiyel sağlayabilmektedir (Uşaklı, 2006). Yaratıcı drama etkinlikleri sayesinde çocuklar, kendilerini özgürce ifade edebilmekte, maskelerinden kurtulup özgüvenlerini ortaya çıkarabilmektedirler (Çalıskan, 2005). Benlik algısı düşük, özgüven bakımından yetersiz olan çocukların akranlarıyla sosyal ilişkiler kurmakta zorlanacakları, bir grup içerisinde söz almaktan kaçınarak yalnızlaşacakları düşünüldüğünde; bu tarz durumdan etkilenen çocukların sınıf içerisindeki başta akademik olmak üzere diğer etkinliklere de katılım sağlamada yetersiz kalabilecekleri görülmektedir.

Sınıf içi etkinliklere katılım; öğrencinin istenen davranışı kazanması için kendisine sağlanan işaretlerle belli bir düzeyde açık ya da örtük olarak etkileşmesi ve bu çabayı davranışı kazanıncaya kadar sürdürmesidir (Bloom 1976). Öğretim ortamında öğrencilerin ilgisini çekmenin ve bunu sürdürmenin sırrı öğrencinin sınıf içi etkinliklere katılımını sağlamaktır (Aksoy, 2000). Ancak öğrencinin etkinliklere katılımını etkileyen birçok unsur vardır. Bu etkenlerin başında öğretme öğrenme ortamı ve öğrencinin özellikleri gelir. Öğrencinin özel ve genel yetenekleri, öğrencinin yavaş ya da hılı öğrenme durumu, aç, uykulu ya da hasta olması, psikolojik olarak rahat olup olmaması etkinliklere katılımını etkiler. Bunun yanında öğrenme ve öğretme ortamında öğretmenin tutumu, dersi işleme biçimi, iletişim becerileri, öğretim yöntem ve teknikleri, sınıfin fiziksel özellikleri de sayılabilir. Katılımı etkileyen ortam ve öğrenci özellikleri göz önüne alındığında özel gereksinimli bir bireyin öğrenme açısından getirdiği dezavantajlar ve yetersizlikler -gerekli düzenlemeler yapılmadığında- öğrencinin başarısız olmasına neden olur. Kaynaştırma eğitimindeki aksaklıklarla beraber, kaynaştırma öğrencilerinin derslerdeki olumsuz yaşantıları da özgüven seviyelerinin düşük olmasına yol açar. Özgüven seviyesinin düşüklüğüyle birlikte, bireyin ve gelişimin bir bütün olduğu göz önüne alındığında, akademik alandaki başarısızlıkların sosyal alana da yansıyacağını görmek olağan bir durumdur. Öğrenme ortamlarında olumsuz yaşantı biriktiren çocukların öğrenmeye karşı isteksiz hale gelmesi ve motivasyon kaybı yeni öğrenmeler edinmesinin önüne geçmekte, bu da öğrenmeye karşı istek duyma, merak etme, yeni öğrenmeler talep etme, derse katılma, cevap verme, 
fikir ifade etme gibi alanlarda anlamlı farklılıklara neden olmaktadır. Yaratıcı dramanın felsefesinde yer alan ve uygulama sürecinin getirdiği eşitlik, sıkça onanıp başarılı hissetme, bütünün bir parçası olduğunun farkına varma, duygularla iç içe olma, hata yapma özgürlügünün olması, bireyi güvende hissettirmektedir. Yaratıcı drama etkinliklerinde oyunlardan faydalanılması süreci eğlenceli hale getirmektedir, bu durum çocuğun öğrenmeyi talep etmesini sağlar. Yaratıcı dramanın oyunsu bir süreç olduğu düşünülürse katılımcının bu süreçte kazanma ve kaybetmenin normal bir durum olduğunu etkinlik içerisinde gelişen empatik süreçle fark etmesi, içselleştirmesi beklenen bir durumdur. Özel gereksinimli bireylerin öğrenmeye karşı olan olumsuz tutumları düşünüldüğünde yaratıcı drama bir yöntem olarak da yukarda söz edilen nedenlerden dolayı güçlü bir araçtır. Ayrıca yapılandırmacı yaklaşım doğrultusunda yenilenen Hayat Bilgisi dersi öğretim programında kazandırılması beklenen eleştirel düşünme, yaratıcı düşünme, iletişim, problem çözme gibi beceriler ile özsaygı, özgüven, hoşgörü, saygı, sevgi, yeniliğe açıklık gibi kavramlar yaratıcı dramanın doğasında dinamik bir biçimde bulunmaktadır (MEB 2009).

\section{Araştırmanın Amacı}

Çalışmanın amacı, genel eğitim sınıfına devam eden kaynaştırma öğrencisinin sınıf içi etkinliklere katılım düzeyine yaratıcı dramanın etkisini araştırmaktır. Bu genel amaç doğrultusunda; deneğin gözlem formlarına dayalı olarak aşağıdaki sorulara yanıt aranmıştır:

1. Deneğin arkadaşlarıyla etkileşimde bulunma düzeyi nedir?,

2. Deneğin liderle/öğretmenle etkileşimde bulunma düzeyi nedir?

3. Deneğin etkinliklere karşı tutumu ile genel performansı nasıldır?

\section{Yöntem}

\section{Araștırmanın Modeli}

Tek denekli araştırma desenleri, nicel deneysel modeller içerisinde yer alan, benzer özellikte denek gruplarına ulaşmanın güç olduğu durumlarda kullanılan desenlerdir. Bu model araştırmalarda veriler grafiksel ve istatistiksel olarak analiz edilir (Kırcaali-İftar 2012). Araştırma tek denekli araştırma modellerinden ABA temel modelinde desenlenmiştir, bu model temel tek denekli tasarımdır. ABA modelinin tek bir uygulamanın etkililiğini incelemeye çalıştığı söylenebilir (Tekinİftar, Kırcaali-iftar 2012). Araştırmanın bağımsız değişkeni yaratıcı drama iken bağımlı değişkeni sınıf içi etkinlik katılım düzeyi olarak belirlenmiştir.

\section{Çalışma Grubu}

Araştırmanın çalışma grubu, Konya'nın Meram ilçesinde bulunan bir ilkokulun 2. sınıfina devam eden, normal gelişim gösteren, sosyo-ekonomik düzeyi düşük ve orta 13 erkek, 6 kız ve öğrenme güçlügüne sahip bir kız çocuktan oluşmuştur. Çalışma grubu amaçlı örneklem yoluyla belirlenmiştir. Amaçlı örneklem araştırmacının belli özelliklere sahip bir örneklemde derinlemesine bilgi sağlamak için tercih ettiği bir yöntemdir (Büyüköztürk vd., 2017). Örneklem seçilirken şu özelliklere sahip olması aranmıştır: Okulun sosyoekonomik olarak düşük bir bölgede yer alması, drama çalışmalarına uygun halı zeminli geniş bir salonunun bulunması, çalışma yapılacak sınıf mevcudunun 24 öğrenciden az olması, drama etkinliği için gönüllü olmaları, sınıfta kaynaştırma 
tanılı öğrencinin bulunması, kaynaştırma öğrencisinin öğrenme güçlügü tanısı almış olması, öğrencinin derslere katılım göstermemesi ve hareketli oyunlara katılmasını engelleyecek herhangi fiziksel ya da duyusal yetersizliğinin olmaması aranan özelliklerdir. Denek 8 yaşında, düşük sosyo ekonomik düzeye sahip, öğrenme güçlüğü tanısı almış, sınıfın yaş olarak en küçük öğrencisidir. Öğretmen ifadelerine göre; 20 kişilik genel eğitim sınıfında en arkaya oturan, derslerde söz hakk1 almayan, kendini ifade etmeyen ve bu firsatı bulamayan, akranları tarafından dışlanmış, serbest zaman etkinlikleri, oyun, fiziksel aktiviteler, resim vb. derslerde de dişarıda kalan bir öğrencidir.

Çalışma, on dört hafta boyunca haftada bir kez gerçekleştirilen 45 dakikalık yaratıcı drama oturumundan oluşmaktadır. Yapılacak etkinlikler ve planlar, yaratıcı drama alanında uzmandan görüş alınarak hazırlanmış, oturumlar yaratıcı drama alanında uzman bir lider/eğitmen tarafından yürütülmüştür. Yaratıcı drama çalışmaları halı zemini olan okulun bodrum katında yer alan bir sınıfta gerçekleştirilmiş, etkinliklerin gerektirdiği müzik ve materyaller sağlanmıştır.

\section{Veri Toplama Araçları}

Ölçme aracı, araştırmacı tarafından geliştirilen bir gözlem formudur. Form hazırlanırken iki farklı uzman görüşü alınmıştır. Etkinlik katılım kontrol listesi üç farklı alanda öğrencinin düzeyini belirlemeye yöneliktir. $\mathrm{Bu}$ alt alanlarda arkadaşlarıyla etkileşimde bulunma, lider/öğretmenle etkileşimde bulunma ve etkinliğe karşı olumlu tutum ve performans düzeyi yer almaktadır. Her maddenin en az 0 , en çok 5 olmak üzere 6 puan değeri üzerinden puanlanması istenmiştir. Alınan puanlar üç alt başlığa genel performans da eklenerek grafiklere dönüştürülmüştür.

Verilerin güvenirliğini desteklemek adına 3 gözlemciden de çocuğun mevcut performansı hakkındaki görüşleri alınmış. Gözlemcilerden her hafta için gözlemlerini yazmalarını ve deneğin süreç boyunca betimlenmesi istenmiştir. Toplanan gözlemler betimsel analizle çözümlenmiştir.

\section{Verilerin Toplanması}

Çalışmanın konusu olan denek üç farklı gözlemci tarafından gözlenmiştir. Birinci gözlemci, uygulamaları yürüten yaratıcı drama eğitmeni olup aynı zamanda özel eğitim lisans programına devam etmektedir. Ayrıca yaratıcı drama alanında dört yıllık bir deneyime sahiptir. İkinci gözlemci çalışmaların yürütüldüğü ve deneğin bulunduğu sınıfın öğretmenidir. Öğretmen okulu mezunu olup, 20 yıllık mesleki deneyime sahiptir. Ancak özel eğitim ve yaratıcı drama alanında herhangi bir eğitime katılmamıştır. Üçüncü gözlemci ise deneğin destek eğitim öğretmenidir. Sınıf öğretmenliği alanında lisans mezunu olup özel eğitim uzman öğretici kursuna katılarak özel eğitim alanına devam etmektedir. Aynı zamanda yaratıcı drama eğitimi almıştır.

Çalışma, düşük ve orta sosyoekonomik düzeye sahip bir ilkokulda, okulun bodrum katında bulunan halı zemine sahip sınıfta deneğin tüm sınıfıyla beraber yürütülmüştür. Çalışma, 2015-2016 eğitim öğretim yılının bahar döneminde, her cuma günü 45 dakika sürecek şekilde, haftada bir oturum olmak üzere uygulanmıştır. Uygulamada 3 oturum deneğin uygulama öncesi performansının alınması, 8 oturum yaratıcı drama uygulamasının yapılması, 3 hafta genelleme performansının (deneğin farklı ortamlarda ve etkinliklerdeki düzeyini) alınması olmak üzere 14 hafta olarak planlanmış ve gerçekleştirilmiştir.

Uygulamaya konulan yaratıcı drama atölyeleri bir uzman tarafından kontrol edilmiştir. Uygulama öncesinde araştırma ve araştırmanın konusu gözlemcilerle paylaşılmış, üç hafta boyunca 
cuma günleri sınıf öğretmeninin hazırladığ1 ve uyguladığı etkinliklerde deneğin performansı kontrol listesi aracılığıyla puanlanmış, başlangıç düzeyi üç gözlemci tarafından betimlenmiştir. Uygulama öncesi performansın alınmasının ardından yaratıcı drama liderinin uygulamalarına geçilmiş, uygulama sırasında iki farklı gözlemci herhangi bir müdahalede bulunmaksızın gerçekleşen etkinlikleri izlemiş, diğer gözlemci etkinliği yürütmüş, ardından tüm gözlemciler kontrol listelerini doldurmuş ve görüşlerini yazılı olarak vermişlerdir. Yaratıcı drama uygulamalarının 6. oturumunda denek tüm gözlemciler tarafından en yüksek puanı almış, 7. ve 8. oturumda da bu performansı sürdürmeyi başarmıştır. Yaratıcı drama oturumları bittikten sonra deneğin mevcut performans genelleme düzeyinin belirlenmesi için haftada bir kez olmak üzere üç hafta daha sınıf öğretmeninin deneğin kendi sınıfında ve bahçede yaptırdığı etkinlikler izlenerek alınmıştır.

\section{Bulgular}

Kaynaştırma öğrencilerinin sınıf içi etkinliklere katılım düzeyini araştıran bu çalışmada; kaynaştırma öğrencisinin arkadaşlarıyla etkileşimde bulunma düzeyi, liderle/öğretmenle etkileşimde bulunma düzeyi ve etkinliklere karşı tutum düzeyini ortaya koymak amaçlanmıştır.

Araştırmanın birinci denencesinde yaratıcı dramaya etkinliklerinin kaynaştırma öğrencisinin sınıf içinde arkadaşları ile etkileşimini olumlu yönde artıracağı kabul edilmiştir. Deneğin arkadaşlarıyla etkileşimde bulunmasına ilişkin gözlem formlarına dayalı olarak elde edilen veriler Grafik 1'de gösterilmiştir.

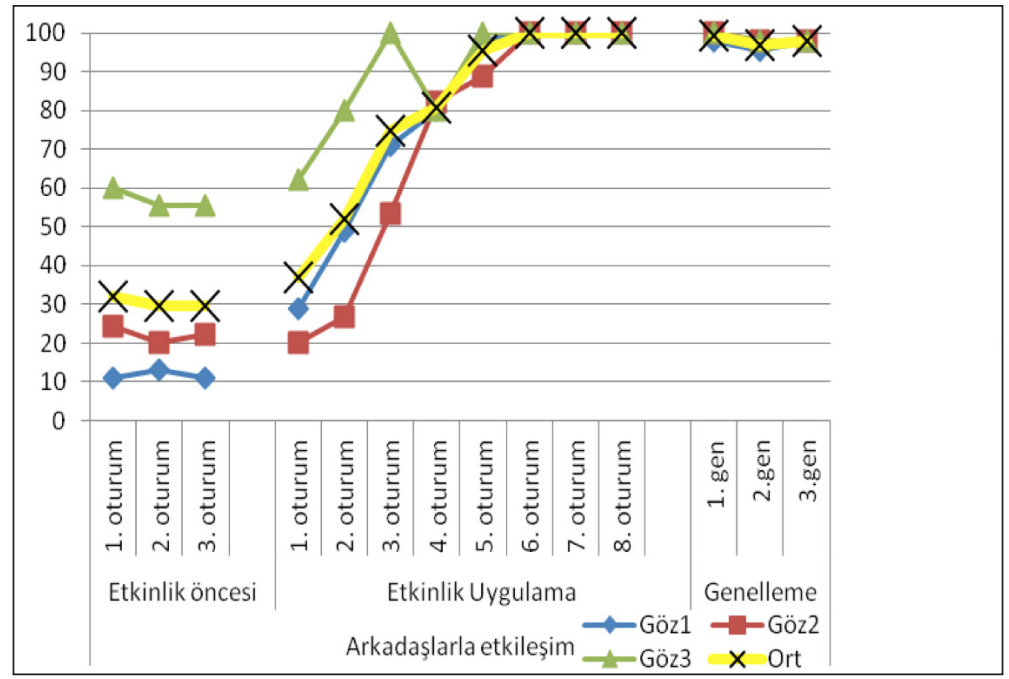

Grafik 1. Arkadaşlarıyla Etkileşimde Bulunmasına İlişkin Elde Edilen Veriler

Arkadaşlarıyla etkileşimde bulunmaya ilişkin elde edilen verilerin yer aldığ grafik 1 incelendiğinde; öğretmen ifadelerine ve derecelendirme formuna göre bu alan deneğin en düşük performans gösterdiği alandır. Etkinlik öncesi ortalama puan açısından deneğin arkadaşlarıyla etkileşim düzeyinin 30 puan dolaylarında olduğu ve verilerin kararlılığ ile verilen puanların paralel olduğu ancak yaratıcı drama oturumlarının devam etmesiyle deneğin arkadaşlarıyla etkileşiminin arttığ1 görülmüştür. Genelleme oturumlarında ise etkileşim düzeyinin korunduğu söylenebilir. 
Gözlemcilerin gözlem sonuçlarından elde edilen verilerde uygulama öncesinde arkadaşlarıyla etkileşim kurmada deneğin dışlandığı, yalnız olduğu, çekindiği, mutsuzluğu, soğuk ve yabancı oluşu ön plana çıkmıştır.

Liderle etkileşimde bulunma alanında; deneğin etkinliği sürdüren yetişkinden söz hakk1 istemesi, görevler dağıtılırken talepte bulunmas1, verilen görevleri yapması, etkinlik içindeki sorumluluklarını yerine getirirken dönütte bulunması, sorulan sorulara cevap vermesi gibi alanlarda düzeyin yaratıcı drama ile arttırılacağı öngörülmüştür.

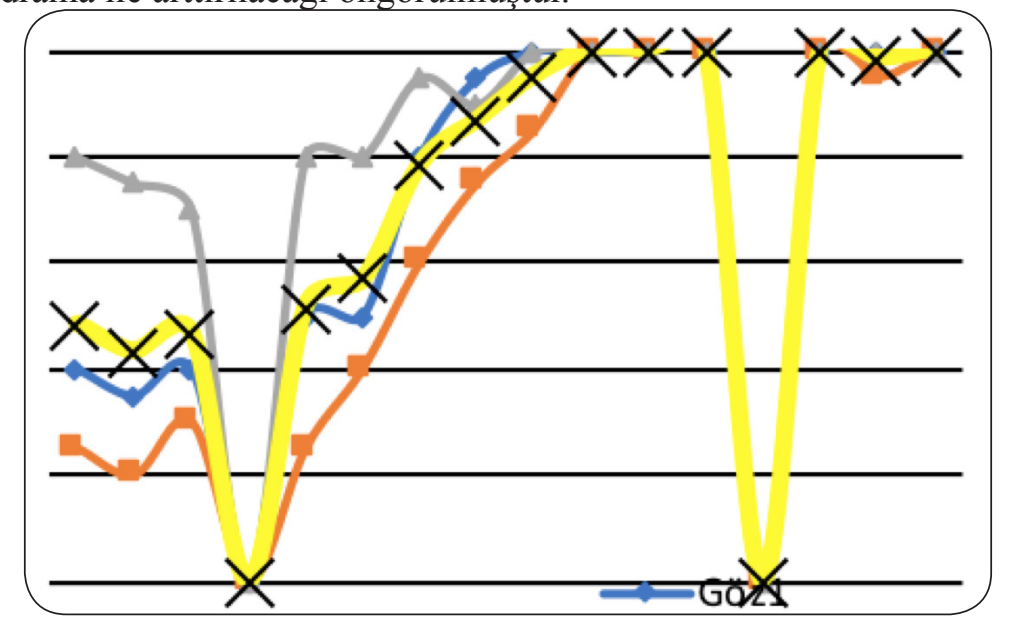

Grafik 2. Liderle Etkileşimde Bulunmasına İlişkin Elde Edilen Veriler

Grafik 2 incelendiğinde; deneğin liderle etkileşimde bulunma düzeyinin başlangıçta 50 puan dolaylarında olduğu ve verilerin kararlılı̆̆1, verilen puanların paralel olduğu görülmektedir. Yaratıcı drama oturumlarının devam etmesiyle bu alanda da öğrencinin performansının gittikçe arttığı ve genelleme oturumlarında bunun devam ettiği söylenebilir.

Bu alanla ilgili gözlemcilerin gözlem sonuçlarından elde edilen verilerde uygulama öncesinde deneğin söz hakk1 istemediği, verilen yönergelere uymadığ1, sorulan sorulara cevap vermekten kaçındığı, utandığı yer almaktadır.

Çalışmadaki bir diğer alan olan etkinliklere karşı olumlu tutum gösterme ve etkinlik performansı alanında; denekten etkinliğe isteyerek katılması, etkinliği başından sonuna kadar sürdürmesi, etkinlik sırasında mutlu görünmesi, kurallara uyması, ihtiyaç duyduğunda yardım talebinde bulunması, gerektiğinde liderlik etmesi, görev üstlenmesi gibi ölçütlerde yaratıcı dramanın etkiliği incelenmiştir. Aşağıdaki grafikte deneğin etkinliklere karşı tutumu ve performansı gösterilmektedir. 


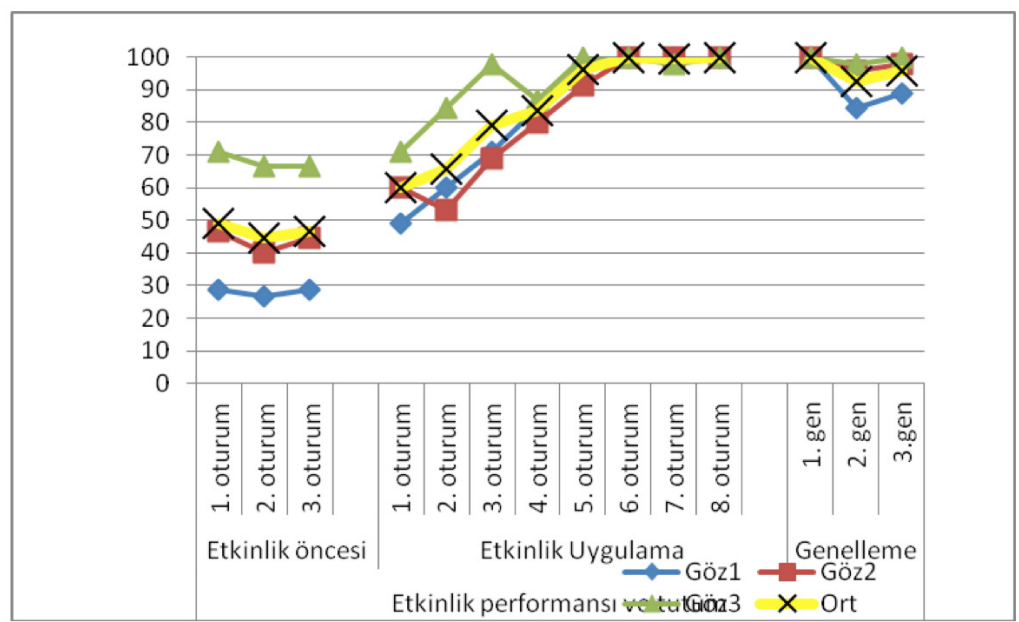

Grafik 3. Deneğin Etkinlik Performansı ve Tutumuna İlişkin Elde Edilen Veriler

Grafik 3 incelendiğinde; deneğin etkinliklere karşı tutumunun ve performansının kontrol listesine göre başlangıçta 45 puan dolaylarında olduğu, verilerin kararlı ve paralel olduğu, yaratıcı drama oturumlarıyla beraber deneğin bu alanda da ilerleme kaydettiğini ve bunu genelleme oturumlarında da sürdürdüğü görülmektedir.

Gözlemcilerden alınan nitel verilerde ise uygulama öncesinde deneğin rekabet etmediği, etkinlikler esnasında mutsuz ve isteksiz olduğu, etkinliklerin dışında kaldığı, etkinlikleri sürdüremediği, kendini değerlendirmediği, yönergelere uymadığı, verilen görevi yerine getirmede özensiz olduğu ifade edilmiştir.

Şimdiye kadar sözü edilen tüm alanların tamamının ortak olarak değerlendirileceği aşağıdaki grafikte deneğin kontrol listesine göre aldığı toplam puanlar gösterilmektedir.

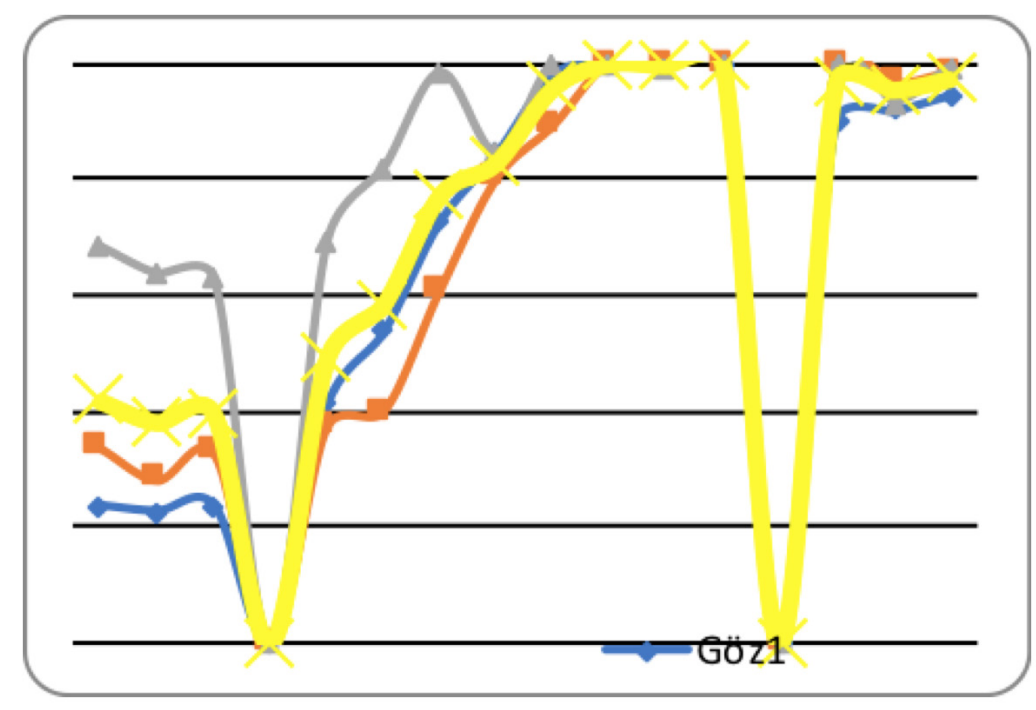

Grafik 4. Deneğin Genel Performansına İlişkin Veriler

Grafik 4'te deneğin tüm alt başl1kların dahil olduğu genel performansı görülmektedir. Deneğin genel performansının 40 puan dolaylarında olduğu, uygulamalarla beraber aldığı puanların giderek 
yükseldiği ve genelleme oturumlarında da bu performans1 sürdürdüğü, gözlemcilerin puanlarında paralellik olduğu görülmektedir.

Uygulama öncesi performansının nitel olarak betimlemesinde gözlemciler; öğrencinin etkinliklerde geride durduğundan, rekabet etmediğinden, çekindiğinden, arkadaşları tarafindan dışlandığından, oyunun ve etkinlik dışında kaldığından, mutsuz ve isteksiz oluşundan, fiziksel ve zihinsel olarak zayıf olduğundan, okula ve arkadaşlarına karşı soğuk ve yabancı olduğundan, sorulan sorulara utanarak cevap vermesinden ve bunların akademik alanı da etkilediğinden söz etmişlerdir.

Yaratıcı drama oturumlarının devam ettiği ve son oturum dahilinde alınan nitel verilerde; deneğin arkadaşlarıyla etkileşimde bulunduğu, oyun ve etkinlikleri sürdürebildiği, öğretmenlerinden yardım beklemediği, etkinliklerden zevk aldığı, mutlu göründüğü, grup oluşturabildiği, gruplara dahil olabildiği, sınıfıyla uyum içinde olduğu, etkinliklerinden sonra öz değerlendirmesini yapabildiği, kendini iyi ifade ettiği, duygu ve düşüncelerini paylaştığı, sorulan sorulara utanmadan cevap verdiği, okumada istekli olduğu ve akademik alanda da istekli olmaya başladığı, artık ön sırada oturduğu dile getirilmiştir. Denek için "Solmak üzere olan bir çiçeğin yeniden canlandı̆̆̆” ifadesi kullanılmıştır. Yaratıcı drama çalışmalarının denek için çok faydalı oluğunu, akademik fayda sağlayabileceğini, programlarda yaratıcı dramaya yer verilmesi gerektiğini ve kaynaştırma öğrencileri ile ilgili etkinlikler yapılması gerektiğini söylemişlerdir. Deneğin bu davranışı sürdürdüğü genelleme oturumlarında görülmektedir.

\section{Tartışma, Sonuç ve Öneriler}

Araştırma yaratıcı drama dersi alan kaynaştırma öğrencisinin sınıf içi etkinliklere katılım düzeyine etkisini belirlemek amacıyla yapılmıştır. Bu kapsamda; nicel ve nitel veriler toplanmış, elde edilen veriler analiz edilmiştir. Yaratıcı drama çalışmalarından önce deneğin etkinliklere katılmak istemeyen, söz hakk1 almayan, başladığı etkinliği yarıda bırakan, öğretmenle ve arkadaşlarıyla iletişime geçmekten kaçınan bir performans sergilediği ancak yaratıcı drama uygulamaları sonrasında arkadaşlarıyla etkileşimde bulunduğu, arkadaş grubunda kendine yer bulabildiği, etkinliklere isteyerek katıldığı, etkinlik esnasında mutlu olduğu ve bunu sürdüğü, söz aldığı, kendini ifade ettiği görülmüştür. Benzer şekilde Yaşaran (2009) normal gelişim gösteren öğrencilerin özel gereksinimli bireylerin sosyal kabullerini sağlamada kaynaştırmaya hazırlık etkinliklerinin etkiliğini incelemiş ve bu etkinliklerin olumlu gelişmeler yarattığı sonucuna ulaşmıştır. Aynı şekilde Öztürk-Özgönel (2012) otizm tanılı kaynaştırma öğrencilerinin bulunduğu sınıflarda akran ilişkilerinin geliştirilmesine yönelik eğitim programının etkililiğini incelemiş ve etkili olduğunu saptamıştır.

Kaynaştırma öğrencisi, liderle/öğretmenle etkileşimde bulunma, iletişim kurma, sürdürme, söz hakkı isteme, yardım isteme konusunda olumlu gelişmeler göstermiştir. Guli vd. (2013)'nin yaptığ1 pilot çalışmada otizm spektrum bozukluğu, dikkat eksikliği ve hiperaktivite bozukluğu, öğrenme güçlüğü olan bireylerle yaptığı yaratıcı drama çalışmalarının sosyal becerileri geliştirdiğini ortaya koymuştur. Benzer şekilde Boran (2010), risk gruplarıyla sosyal alanda yaratıcı drama çalışmalarının etkilerini zihin engelli ve öğrenme güçlüğü olan bireyler üzerinden incelemiş ve temel sosyal beceriler, saldırgan davranışlarla başa çıkma becerileri, ileri konuşma becerileri, bilişsel beceriler ve ilişkiyi başlatma becerilerini geliştirici etkisi olduğunu ortaya koymuştur. Önalan-Akfirat (2004) yaratıcı dramanın işitme engelli bireylerin sosyal becerilerinin geliştirilmesinde etkili olduğunu, Alp (2008) sosyal uyum bozukluğu gösteren çocukların uyumsal davranışlarına kaynaştırılmış ders 
dışı hareket ve oyun etkinliklerinin etkisini incelemiş ve sosyal uyum problemi gösteren çocuklarda iyileşme saptamıştır. Başka bir çalışmada Çetin (2005) zihin engelli öğrenciler için hazırlanan sosyal beceri öğretim programının etkililiğini incelemiş ve etkili olduğunu saptamıştır.

Kaynaştırma öğrencisi; etkinliklere olumlu tutum geliştirme, etkinliğe katılma, etkinlik sırasında istekli ve mutlu olma, kendini ifade etme, değerlendirme, etkinlikte tam performans gösterme konusunda olumlu gelişmeler göstermiştir. Araştırma sonucunda elde edilen verilerde yer alan bu olumlu gelişmelerin öğrencinin akademik alanda başarısını artırması alan yazında birçok çalışmayla desteklenmiştir. Bu çalışmada ise yaratıcı drama dersinin kaynaştırma öğrencisinin sınıf içi etkinliklere katılımını artırdığı gösterilmiştir.

Araştırma sonucunda elde edilen veriler doğrultusunda aşağıdaki önerilerde bulunulabilir:

- Kaynaştırma öğrencilerinin dezavantajlı olduğu bilinmektedir bu dezavantajlar öğrencilerin sınıfıyla bütünleşmelerini olumsuz yönde etkileyebilir. Bu etkilenme olmaksızın kaynaştırma öğrencilerinin sınıflarında, sınıfın bütünlügünü sağlayacak yaratıcı drama etkinlikleri yapılabilir.

- Başka bir disiplin ya da yöntemle yaratıcı dramanın etkililiği karşılaştırılabilir.

- Kaynaştırma öğrencilerinin sosyal kabulü ve sınıf içi etkinliklere katılımının artırmasını sağlayabilecek farklı disiplin ya da yöntemlerin etkililiği araştırılabilir. 


\section{Kaynakça}

Adıgüzel, Ö. (2013). Eğitimde yaratıcı drama. Ankara: Pegem Akademi Yayıncılık.

Aksoy, S. (2000). Öğrencilerin derse katılımını sağlama yolları. Bilim ve Aklın Aydınlığında Eğitim Dergisi, 15(3), 28-40.

Alp, H. (2008) Sosyal uyum bozukluğu gösteren çocukların uyumsal davranışlarına kaynaştırılmış ders dışı hareket ve oyun etkinliklerinin etkisi. (Yayınlanmamış Yüksek Lisans Tezi). Celal Bayar Üniversitesi. Sağlık Bilimleri Enstitüsü. Manisa.

Batu, S. ve Kırcaali-İftar, G. (2006). Kaynaştırma, Ankara: Kök Yayıncılık.

Bloom, B. S. (1976). Human characteristics and school learning. New York: McGrawHill.

Boran, E. (2010). Risk gruplarıyla sosyal alanda yaratıcı drama çalışmalarının etkisi. (Yüksek Lisans Tezi). İstanbul Üniversitesi. Sosyal Bilimler Enstitüsü. İstanbul.

Büyüköztürk Ş., Kılıı̧-Çakmak E., Akgün E.Ö., Karadeniz Ş., Demirel F. (2017). Bilimsel araştırma yöntemleri. Ankara: Pegem Akademi Yayıncıllk.

Çalışkan, A. (2005) Ruhsal ve bedensel rahatlı̆̆n yeni adresi 'Yaratıcı drama kulüpleri'. Yeni Asır, Pazar Sarmaşık, (1).

Eldeniz-Çetin, M. (2005) Zihin engelli öğrenciler için drama yöntemine göre hazırlanan sosyal beceri öğretim programının etkililiğinin incelenmesi. (Yayınlanmamış Yüksek Lisans Tezi). Abant İzzet Baysal Üniversitesi. Sosyal Bilimler Enstitüsü. Bolu.

Genç, N. H. (2003). Eğitimde yaratıcı dramanın alımlanması. Hacettepe Üniversitesi Eğitim Fakültesi Dergisi. (24) 196-205.

Guli, L. A., Semrud-Clikeman, M., Lerner, M. D., \& Britton, N. (2013). Social Competence Intervention Program (SCIP): A pilot study of a creative drama program for youth with social difficulties. The Arts in Psychotherapy, 40(1), 37-44.

Güzel-Özmen, R. (2009). Kaynaştırma ortamlarında öğretimsel düzenlemeler. A. Ataman(Ed.), Özel gereksinimli çocuklar ve özel eğitime giriş (s59-86). Ankara. Gündüz Eğitim ve Yayıncılık.

Isenberg, J.P. and Jalongo, M.R. (1993). Creative expression and play in the early childhood curriculum. Simon \& Schuster Books For Young Readers.

Kırcali-İftar G, (2012). Tek denekli araştırmaların tarihçesi. E. Tekin-İftar (Ed.), Eğitimde Tek denekli araştırma yöntemleri s(1-10). Ankara: Türk Psikologlar Derneği Yayınları.

MEB (1973) Milli Eğitim Temel Kanunu, 14574 sayılı Resmi Gazete.

MEB (2006) 26184 say1l Resmi Gazete.

MEB (2006). Özel eğitim hizmetleri yönetmeliği.

Önalan-Akfırat F. (2004). Yaratıı dramanın işitme engellilerin sosyal gelişimine etkisi. Ankara Üniversitesi Eğitim Bilimleri Fakültesi Özel Eğitim Dergisi 5(1), 9-22.

Özkan-Yaşaran, Ö. (2009). Normal gelişim gösteren öğrencilerin özel gereksinimli bireylerin sosyal kabullenirini sağlamada kaynaştırmaya hazırlıklarının etkisi. (Yayınlanmamış Yüksek Lisans Tezi). Anadolu Üniversitesi. Eğitim Bilimleri Enstitüsü. Eskişehir.

Öztürk-Özgönel, S. (2012). Otizm tanılı kaynaştırma öğrencilerinin bulunduğu sınıflarda akran ilişskilerinin geliştirilmesine yönelik bir eğitim programının etkililiğinin incelenmesi. (Yayınlanmamış Doktora Tezi). Dokuz Eylül Üniversitesi. Eğitim Bilimleri Enstitüsü. İzmir.

San, İ. (2002). Eğitimde yaratıcı drama H.Ö. Adıgüzel. (Ed.), Yaratıcı drama Ankara: Naturel yayıncılık.

Sucuoğlu, B. ve Kargın, T. (2006). İlköğretimde kaynaştırma uygulamaları, İstanbul: Morpa Yayınları.

Tekin-İftar, E. ve Kırcaali-İftar G. (2012). Yanlıssız öğretim yöntemleri, Ankara: Vize yayıncılık.

Uşakl1, H. (2006) Drama temelli grup rehberliğinin ilköğretim V. sınıf öğrencilerinin arkadaşlı ilişsileri, atılganlık düzeyi ve benlik saygısına etkisi. (Yayınlanmamış Doktora Tezi). Dokuz Eylül Üniversitesi, Eğitim Bilimleri Enstitüsü, İzmir. 


\section{EK I: Örnek Oturum Planı}

Tarih: 08. 04. 2016

Konu: Etkileşim

Mekan: Yunus Emre İlkokulu Çok Amaçlı Salonu

Katılımcılar: 2A sınıfı öğrencileri 13 erkek $7 \mathrm{~K} 1 \mathrm{Z}$

Süre: 45 dakika

Araç ve gereç: Davul, taşıt resimleri, a4 kağıdı, kalem.

Yöntem/Teknik: Yaratıcı Drama (rol oynama, doğaçlama)

\section{Kazanım:}

1. Arkadaşlarıyla etkileşimde bulunur.

2. İletişim kurar.

3. Arkadaşlarıyla takım olarak hareket eder.

\section{SÜREÇ}

\section{Isınma}

Eğitmen çocuklarla çemberde buluşur ve herbirine nasıl hissettiğini sorar.

1. Etkinlik: Eğitmen davulu çocuklara gösterir. Eğitmen adını davula vurarak, tartımlayarak, ismini söyler. Davul sırayla çemberde gezer ve her çocuk adını tartımlar. İlk tur bitince ikinci turda çocuklar adlarının tartımını vururlar, arkadaşları vuran kişinin ismini söyler.

2. Etkinlik: Çocuklar ayağa kalkarlar. Eğitmen bir otomobil resmi gösterir. 'Şimdi hepiniz arabasınız. Davul yavaş ya da az sesli çalarsa yavaş, hızlı ve yüksek sesli çalarsa hızlı hareket edeceksiniz' der. Çocuklar davulun ritmine göre hareket ederler.

3. Etkinlik: Eğitmen çocuklara taşıt kartlarının olduğu torbayı uzatır. Her çocuk bir taşıt seçer. Eğitmen davula vurduğunda her çocuk elindeki taşıtın sesini çıkararak ya kendiyle aynı olan taşıtı bulur.

Eğitmen yeniden çocuklara taşıt kartlarının olduğu torbayı uzatır. Her çocuk bir taşıt seçer. Eğitmen davula vurduğunda her çocuk bu kez elindeki taşıtın hareketini yaparak kendiyle aynı olan taşıtı bulur. Sürecin nasıl geçtiği, eş bulmanın kolay olup olmadığı konuşulur.

\section{Canlandırma}

1. Etkinlik: Çocuklar iki gruba ayrılırlar. Eğitmen bir gruba gemi diğer gruba tren resmi gösterir. Gruplardan biri gemi diğeri tren olarak hareket edecektir. Gemi ve tren kopmamalı çok uyumlu hareket etmelidir.

\section{Değerlendirme}

1. Etkinlik: Eğitmen her çocuğa bir A4 kağıdı verir. Her çocuk origami olarak bir gemi yapar ve üzerine nasıl hissettiğini yazar. 
